\title{
原著論文
}

\section{重合様式の異なる市販義歯床用レジンの 適合精度について}

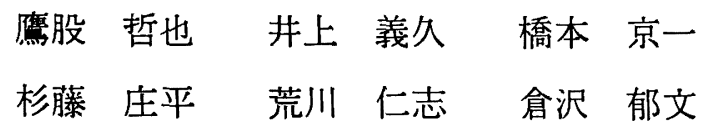

Adaptation of Acrylic Resin Dentures Polymerized Using Various Activation Modes

Tetsuya Takamata, Yoshihisa Inoue, Kyoichi Hashimoto, Shohei Sugitou, Hitoshi Arakawa and Ikufumi Kurasawa

\begin{abstract}
The purpose of this in vitro study was to compare the dimensional accuracy of maxillary dentures made using a conventional heat-activated PMMA resin, a pour resin, a visible light-activated resin, and a microwave-activated acrylic resin.

Two simple methods for measuring dimensional accuracy were used : (1) weight of impression material entrapped between the base and master die and (2) measurement of the posterior border gap at five locations. The volume of space between the denture base and the master die was determined by (1) computation and (2) estimation. Statistical analysis (Bartlett, ANOVA and Tukey's Tests) supported the following conclusions :

(1) all groups showed a processing contraction, most apparent from buccal flange to buccal flange,

(2) the poorest fitting group was processed in a brass flask and a water bath at a temperature which rose from 70 to $100^{\circ} \mathrm{C}$, using a heat activated resin (Acron),

(3) the visible light activated resin (Triad) produced dentures of intermediate accuracy, as did Acupac 20 when either heat or microwave activated,

(4) the two best fitting groups were prepared from a chemically activated resin system using pressure at low heat (PER form), and the resin developed for microwave activation (Acron MC).
\end{abstract}

Key words : adaptation, acrylic resin denture, various activation modes

松本歯科大学歯科補緅学第一講座（指尊：橋本京一教授）

Complete and Removable Partia 1Denture Prosthodontics, Matsumoto Dental College (Chief : Prof. Kyoichi Hashimoto)

平成元年 6 月 9 日受付

\section{I. 緒 言}

義歯床用材料としてアクリル樹脂が使用され始めてか ら，約半世紀が経過しようとしている11.この間, メタア 
表 1 市販義歯床用材料と重合方法

\begin{tabular}{|c|c|c|c|c|c|}
\hline Brand & Type of material & $\begin{array}{l}\text { Batch } \\
\text { No. }\end{array}$ & Manufacturer & $\begin{array}{l}\text { Powder/Liquid } \\
\text { ratio }(\mathrm{gm} / \mathrm{cc})\end{array}$ & $\begin{array}{l}\text { Curing } \\
\text { method }\end{array}$ \\
\hline Acron & Heat activated resin & $\begin{array}{l}\text { Mon. } 220181 \\
\text { Pol. } 281251\end{array}$ & $\begin{array}{l}\text { GC Dental Ind. } \\
\text { Corp., Tokyo, } \\
\text { Japan }\end{array}$ & $100 / 40$ & $\begin{array}{l}\text { Water bath } \\
30 \min \cdots-70^{\circ} \mathrm{C} \\
30 \min \cdots 100^{\circ} \mathrm{C}\end{array}$ \\
\hline \multirow[t]{2}{*}{ Acupac 20} & \multirow[t]{2}{*}{$\begin{array}{l}\text { Heat activated resin } \\
\text { Fast boilable }\end{array}$} & \multirow[t]{2}{*}{$\begin{array}{l}\text { Mon. } 087029 \\
\text { Pol. } 037025\end{array}$} & \multirow{2}{*}{$\begin{array}{l}\text { Howmedica, Inc., } \\
\text { Dental Division, } \\
\text { Chicago, IL }\end{array}$} & \multirow[t]{2}{*}{$100 / 47.6$} & $\begin{array}{l}\text { Water bath } \\
20 \mathrm{~min}^{\cdots} \cdot 100^{\circ} \mathrm{C}\end{array}$ \\
\hline & & & & & $\begin{array}{l}\text { Microwave } \\
13 \mathrm{~min}^{\cdots}-90 \mathrm{~W} \\
1.5 \mathrm{~min}^{\cdots} 500 \mathrm{~W}\end{array}$ \\
\hline PERform & $\begin{array}{l}\text { Chemically activated } \\
\text { pour resin }\end{array}$ & $\begin{array}{l}\text { Mon. } 376042 \\
\text { Pol. } 020784\end{array}$ & $\begin{array}{l}\text { Whaledent Int. } \\
\text { New York, NY }\end{array}$ & $100 / 55$ & $\begin{array}{l}\text { Pressurized } \\
\text { water bath } \\
5.5 \text { bars ( } 1 \text { bars } \\
\fallingdotseq 1 \text { atm) } \\
\text { Cast base under } \\
\text { vacuum } \\
30 \text { min } \cdots 45^{\circ} \mathrm{C}\end{array}$ \\
\hline Triad & $\begin{array}{l}\text { Visible light } \\
\text { activated resin }\end{array}$ & $\begin{array}{l}\text { Rope : } 8001082 \\
\text { Sheet : } 8001857 \mathrm{~A}\end{array}$ & $\begin{array}{l}\text { Dentsply Int. } \\
\text { Corp., York, PA }\end{array}$ & $\begin{array}{l}\text { Single } \\
\text { compo- } \\
\text { nent }\end{array}$ & $\begin{array}{l}2 \text { min (external) } \\
\text { then } 6 \text { min } \\
\text { (internal) }\end{array}$ \\
\hline Acron $\mathrm{MC}$ & $\begin{array}{l}\text { Microwave } \\
\text { activated resin }\end{array}$ & $\begin{array}{l}\text { Mon. } 020761 \\
\text { Pol. } 150761\end{array}$ & $\begin{array}{l}\text { GC Dental Ind. } \\
\text { Corp., Tokyo, } \\
\text { Japan }\end{array}$ & $100 / 43$ & $\begin{array}{l}\text { Microwave } \\
3 \min \cdots 500 \mathrm{~W}\end{array}$ \\
\hline
\end{tabular}

クリレートレジンに関する寸法精度ならびに機械的強度 の向上, 操作性の簡便さ, 重合時間の短縮などについて, 多くの材質的な改良と開発がなされ 2 15)，また，いろい ろな重合方法が紹介されてきた ${ }^{16 ~ 23) . ~ し か し ， い ま た ゙ に ~}$ 義歯床用材料としてメタアクリレートレジンが臨床に広 く使用され，これに代わる優れた材料が出ていないのが 現状である.メタアクリレートレジンが長年にわたって 使用され続けてきている理由には，この材料が優れた審 美性を備えていること, 機械的強度あるいは化学的安定 性が臨床的に満足しうること, 粉液重合法による成形加 工のため取り扱いが比較的容易であること ${ }^{24)}$ な゙゙が考え られる.このようにいくつかの利点を持ち, 義歯床用材 料としてその主流をなすメタアクリレートレジンも硬化 反応が重合反応であることから，モノマーが重合してポ リマーになる時の密度の増加に起因する重合収縮と, 硬 化したレジンが加熱温度から室温まで泠却される間に生 ずる熱収縮とを併せ持ち ${ }^{25)}$, その結果, 重合 後の義歯 に寸法変化が現れ，義歯床の変形 ·人工歯の変位などが 生じる. 臨床上, 義歯床の変形は, 床と粘膜面との適合 を不良にし，義歯床下粘膜組織の疼痛・炎症，歯槽骨吸 収などの障害を引き起こし，義歯の維持・安定を低下さ せることになる．また，人工歯の変位は咬合器上で確立
された咬合関係に狂いを生じさせ，咬合調整に多くの時 間を費やすことになり，不十分な咬合関係のまま製作さ れた義歯を装着することにより，咬合不調和をきたすこ とも考えられる. 近年, これらメタアクリレートレジン の欠点を補うべく，材料そのものの改良，開発とともに いろいろな重合方法が考案され，報告されている26 41).

そこで著者らは，これら各種の重合方法で作製された レジン床義歯の重合収縮に伴う寸法変化を知るために, その評価方法の 1 つである適合精度について検討した.

\section{II. 実験材料と方法}

\section{1. 材料ならひに試料の作製}

材料は加熱重合レジンとして Acron (G-C 社製)，短 時間加熱重合レジンとして Acupac 20 (Howmedica 社 製), 加圧吸引低温重合レジンとして PERform (Whaledent 社製), 光重合レジンとして Triad (Dentsply 社 製)，マイクロ波重合レジンとして Acron MC (G-C 社 製）の 5 種類の義歯床用レジンを用いた. また，短時間 加熱重合レジンの Acupac 20 についてはマイクロ波重 合をも試みた（表 1). 上頡無歯顎堤を想定した ADA 規 格の標点つき金属原型を実験用金型として用いた.この 


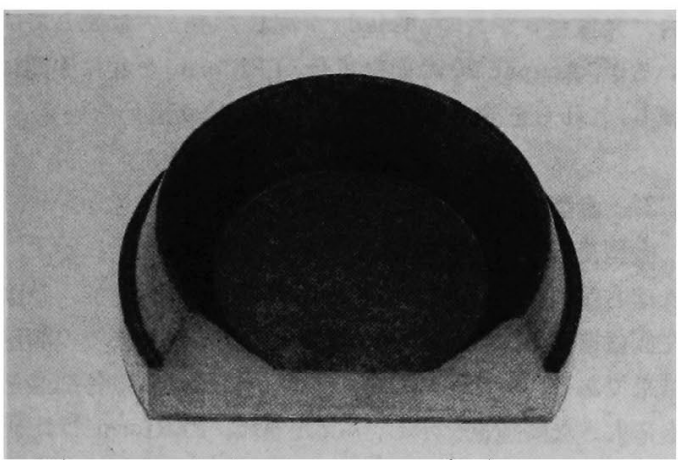

図 1 上顎無菌顎堤を模做した金型

金型は重合後のレジン床義歯を位置づけるために，辺縁 部に 3 力所, 後縁部に 1 力所, 幅・哚さともに約 1.0 $\mathrm{mm}$ のV字状切痕を付与してあるものである (図 1). 常 温加硫シリコーン (General Electric 社製) にて金型の モールドを作製し，タイプ IV 超硬石既 (Columbus Dental 社製)，W/P 0.22 にて石育模型を作製した. そ れぞれ， 7 床ずつ試料を作 製することとし，合計42 個の 石膏模型を作製した. 金型と石亮模型との寸法精度を検 討するため, 標点間距を measuring microscope (Gaertner 社製) にて金型については 7 回測定しその平均を，石 音模型については無作為に選んだ 10 個の模型で 1 個に つき 3 回測定しその平均を求めた.この平均値からさら に 10 個の模型の平均を求め比較した.その結果寸法精度 は $99.97 \%$ (平均標準偏差 0.01\%) で，本実験には十分 使用出来うるものと判断した.

試料は，できる限り臨床的な形態に近く作製するため に人工歯を排列することとし, 咬合器は Verticulator (Jelenko 社製) を使用した. 上弓に石高模型を装着し た後，パテタイプのシリコーン印象材にてコアーを操得 し，以降，すぺての石亮模型と上弓とが同一の位置関係 で装着されるように考虑した. 蠟義歯の調製に際しては， レジン床の厚みをできる限り均一にするために, 金型を 顎堤の唇側面，舌側面ならぴに口蓋面の 3 面に分け，そ れぞれの面に一致した形状のパラフィンワックスをあら かじめ作製し，これを模型上に圧接・適合し，境界部を 溶融結合した. また，圧接に際しては各面のパラフィン ワックスの厚みができる限り均等に保たれるように配虑 した. このようにして, 光重合レジンの Triad に使用 する 7 個の石亮模型を除く, 35 個のすへてて石亳模型に ついて行った. レジン歯 (New Hue Plastic, Dentsply 社製）を用いて人工歯排列を行い，歯頸部のワックスを 整えた後, 蠟義歯人工歯咬合面の石高コアーを採得し,
すべての試料の人工歯と石亮模型との位置関係が同一に なるようにした.

\section{2. 重合方法}

各義歯床用レジンの重合方法を 表 1 に示す. いずれ も使用説明書に従い，それぞれ 7 床ずつ作製した. 短時 間加熱重合レジンの Acupac 20 についてはマイクロ波 重合をも試み, $90 \mathrm{~W}$ で 13 分間の予備重合後, $500 \mathrm{~W}$ 1 分 30 秒間の本重合を行った ${ }^{42)}$. 光重合レジンの Triad については, 石亮模型萼堤部の唇側面, 舌側面そ して口蓋面の 3 面に分けて Triad シートを圧接し, 出 来る限り均等に，空気が混入しないように注意した. 重 合後の寸べての試料は, 通法に従い研磨した後, 蒸留水 中に 21 日間浸漬した.

\section{3. 評価方法}

1）金型と義歯床内面との間にシリコーン印象材を介 在させ,一定荷重条件下で硬化させた後，その重さを計 量する.

シリコーンはプレジデント卵象材ライトボディ (Coltene 社製) を使用し，キャタリストとベースを秤にて正 確に計量した後, 30 秒で練和し，60 秒以内に義歯床の内 面に盛って, 金型に位置うけた後, 荷重装置により義歯 の咬合面に約 $3 \mathrm{~kg}$ の荷重をかけ，辺縁に流れ出た印象 材は奇麗に拭きとった. 練和開始後 3 分 30 秒 で約 $1 \mathrm{~kg}$ の荷重を取り除き, 練和開始 8 分後に残りの約 $2 \mathrm{~kg}$ を 取り除いた. これらの操作はすべて $23^{\circ} \mathrm{C}$, 湿度 $55 \%$ の 温度・湿度コントロール・ルーム内で行った. シリコー ンの計量は, 1 万分の $1 \mathrm{~g}$ まで計量可能な電子天科 (Mettler 社製) を使用し，それぞれの床用レジンにお いて, 各試料につき 3 回ずっ測定してその平均值を求め, この值からさらに 7 個の試料の平均值を求めて 比較 し た.

2）金型の後縁と義歯床後縁との間隙を測定する.

金型後縁の左 右 辺縁 部, 左右歯槽頂部, 口蓋部のそ れぞれの中央における義歯床後縁との垂直的間隙を， measuring microscope (Gaertner 社製) を用いて 3 回 測定し, 平均を求めた. この際, 厚さ約 $2 \mathrm{~cm}$, 直径約 7 $\mathrm{cm}$ のゴム質円板を義歯床人工歯列の切縁ならびに咬合 縁に接触するように置き，この円板の中央部に荷重装置 の先端を位置つけて, 約 $3 \mathrm{~kg}$ の荷重をかけた状態で測 定した.

3） 2) で得られた間隙量から，金型と義歯床内面とに 生ずると思われる辺縁部，歯槽頂部，口蓋部の空間の概 
$204-1504$

略の体積を求める.

この体積には金型顊堤の唇側面と舌側面に生ずると思 われる空間の体積は含まれない，金型各部の底面積の算 出には金型を写真撮影して，実物大に焼き付けた写真を トレースし，デジタイザー（グラフテック社製）にて入 カし, 面積計算プログラムに基づいてパーソナルコンピ ューター (NEC 社製) にて行った. 面積値は 3 回入力の 平均値を用いた.

\section{III. 結 果}

\section{1. シリコーンの重さ}

金型と義歯床内面との間に介在したシリコーンの重さ の測定結果を表 2 , 図 2 に示す. 統計的にはマイクロ波 重合レジンの Acron MC が最も適合が良かった.このグ ループには短時間加熱重合レジンの Acupac 20 の湿熱 重合, 加圧吸引低温重合レジンの PERform がそれぞれ 属するが, Acupac 20 とPERformは Acupac 20 のマイ クロ波重合, 光重合レジンの Triad と共に中間のグル ープにも属し，この值からは Acron MC が最も適合が 良いといえる. 最む適合が悪かったのは, 加熱重合レジ ンの Acron で, この場合もAcupac 20 のマイクロ波重
33 巻 6 号 (1989)

合, 光重合レジンの Triad が同じグループに属しては いるが, Acupac 20 の湿熱重合, PERform と共に中間に 属し、これらを除くとAcronが最も適合が悪いといえる。

\section{2. 金型後緣と義歯床後縁の間隙量}

金型後縁と義歯床後縁の間隙量を表 3 , 図 3 亿示す. A は右側辺縁部， B は右側歯槽頂部，C は口蓋部， D は 左側歯槽頂部， $\mathrm{E}$ は左側辺縁部で各部位の中央での測定 結果である. Acron は，他のレジンに比較して各部位と もに大きな間隙量を示し, Acron MC, PERform は比較

表 2 義菊床内面に残った印象材の重さ（gm）

\begin{tabular}{lccc}
\hline Materials & Activation method & \multicolumn{1}{c}{$\overline{\mathrm{X}}$} & S.D. \\
\hline Acron & Heat & $1.8390(\mathrm{a})^{*}$ & 0.1524 \\
Acupac 20 & & $1.5109(\mathrm{~b}, \mathrm{c})$ & 0.2558 \\
\hline PERform & Chemical & $1.3931(\mathrm{~b}, \mathrm{c})$ & 0.0919 \\
\hline Acron MC & Microwave & $1.3573(\mathrm{c})$ & 0.1112 \\
Acupac 20 & & $1.6405(\mathrm{a}, \mathrm{b})$ & 0.1794 \\
\hline Triad & Visible light & $1.6406(\mathrm{a}, \mathrm{b})$ & 0.1817 \\
\hline
\end{tabular}

* Multiple comparisons using Tukey's procedure. At $\mathrm{p} \leqq 0.05$, groups means designated by the same letter are not statistically different.

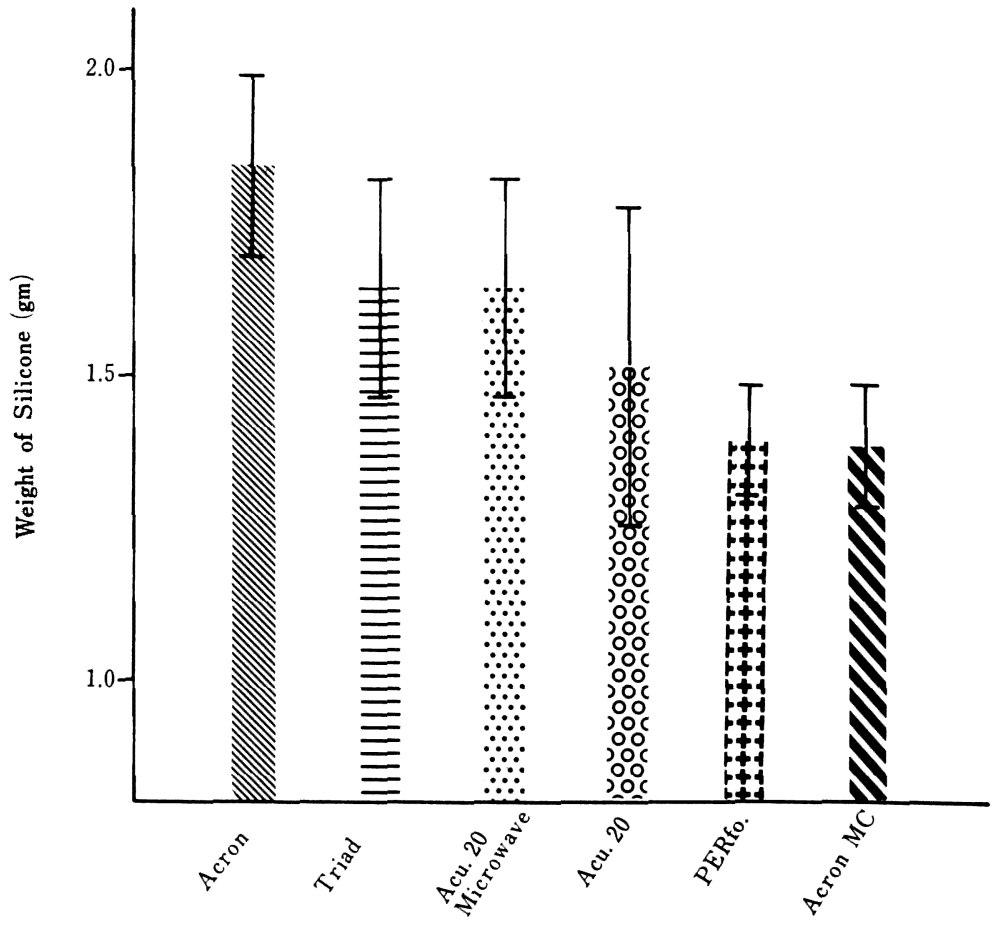

図 2 義歯床内面と金型との間に介在した印象材の重さ 
表 3 義歯床後縁部の浮き上がりの平均値と標淮偏差 $(\mu \mathrm{m})$

\begin{tabular}{|c|c|c|c|c|c|c|}
\hline $\begin{array}{l}\text { Positions } \\
\text { Material }\end{array}$ & & $A$ & 13 & $\mathrm{C}$ & D & $\mathrm{E}$ \\
\hline Acron & $\begin{array}{c}\text { A. } \\
\text { S.D. }\end{array}$ & $\begin{array}{c}288.1: 3(a)^{*} \\
19.233\end{array}$ & $\begin{array}{l}2.3 .43(\text { a }) \\
20.23\end{array}$ & $\begin{array}{l}294.43(a) \\
17.12\end{array}$ & $\begin{array}{l}216.00(\mathrm{a}) \\
18.64\end{array}$ & $\begin{array}{c}263.18(\mathrm{a}) \\
16.59\end{array}$ \\
\hline Acrom $M$ & $\begin{array}{c}\text { Xi } \\
\text { S.D. }\end{array}$ & $\begin{array}{l}84.7 i(c) \\
11.23\end{array}$ & $\begin{array}{l}1.7 .76(\mathrm{~d}) \\
6.19\end{array}$ & $\begin{array}{l}129.67(\mathrm{~d}) \\
10.83\end{array}$ & $\begin{array}{c}74.04(b) \\
7 . .22\end{array}$ & $\begin{array}{l}93.69(\mathrm{c}) \\
9.05\end{array}$ \\
\hline PERform & $\begin{array}{c}\mathrm{X} \\
\text { S.D. }\end{array}$ & $\begin{array}{l}95.49(\mathrm{c}) \\
12.22\end{array}$ & $\begin{array}{l}94.43(b) \\
12.91\end{array}$ & $\begin{array}{c}100.57(\mathrm{e}) \\
9.39\end{array}$ & $\begin{array}{l}74.96(b) \\
12.46\end{array}$ & $\begin{array}{l}97.53(\mathrm{c}) \\
10.85\end{array}$ \\
\hline Triad & $\begin{array}{l}\mathrm{X} \\
\text { S.D. }\end{array}$ & $\begin{array}{l}87.03(c) \\
10.69\end{array}$ & $\begin{array}{l}85.67(b) \\
9.28\end{array}$ & $\begin{array}{c}180.43(\mathrm{c}) \\
14.70\end{array}$ & $\begin{array}{l}70.77(b) \\
10.24\end{array}$ & $\begin{array}{l}74.29(\mathrm{~d}) \\
11.21\end{array}$ \\
\hline $\begin{array}{l}\text { Acupac } 20 \\
\text { Ileat }\end{array}$ & $\begin{array}{c}\mathrm{X} \\
\text { S.I). }\end{array}$ & $\begin{array}{c}118.81(b) \\
11.96\end{array}$ & $\begin{array}{l}83.06(b) \\
11.16\end{array}$ & $\begin{array}{l}224.19(b) \\
14.19\end{array}$ & $\begin{array}{l}64.29(\mathrm{~b}) \\
5.67\end{array}$ & $\begin{array}{l}155.66(\mathrm{~b}) \\
25.74\end{array}$ \\
\hline $\begin{array}{l}\text { Acupac } 20 \\
\text { Microwave }\end{array}$ & $\begin{array}{c}\mathrm{X} \\
\text { S.D. }\end{array}$ & $\begin{array}{c}100.34(\mathrm{c}) \\
4.98\end{array}$ & $\begin{array}{l}60.13(\mathrm{c}) \\
2.78\end{array}$ & $\begin{array}{l}179.40(\mathrm{c}) \\
10.38\end{array}$ & $\begin{array}{l}7 \pi .71(b) \\
8.6 .5\end{array}$ & $\begin{array}{c}110.80(\mathrm{c}) \\
5.68\end{array}$ \\
\hline
\end{tabular}

* Multiple comparisons using Tukey's procedure. At $p \leq 0.05$, groups means designated by the same letter are not statistically different

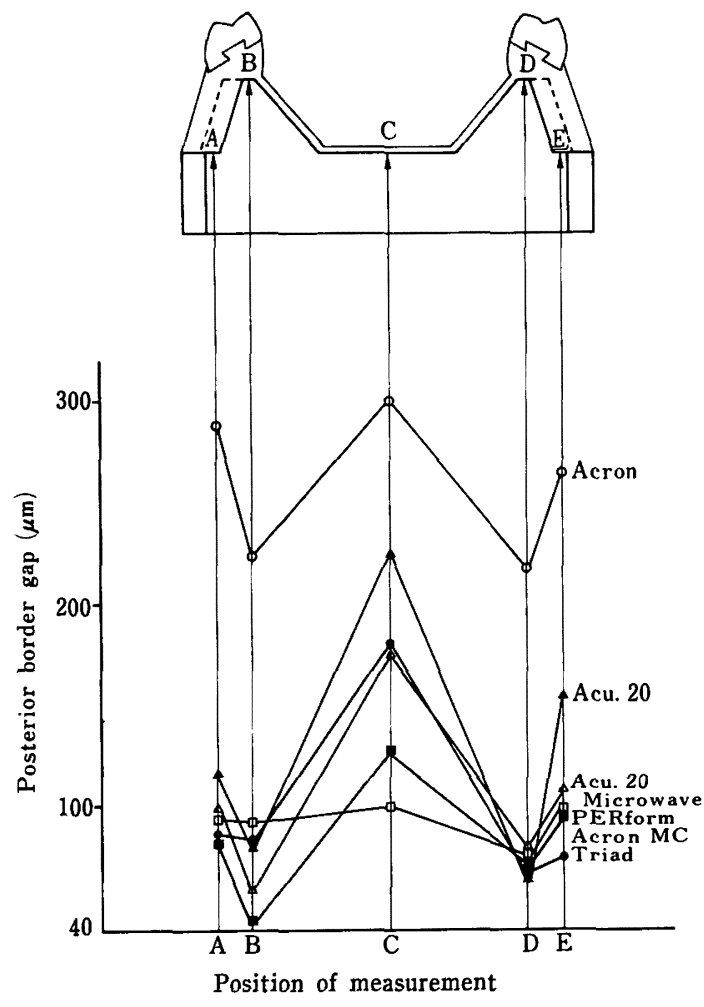

図 3 義歯床後縁部と金型との浮き上がり量

的小さな値を示した. 特に PERform の口蓋中央部にお いて著明であった.

\section{3. 金型と義歯床内面とに生じる間隙の概略の体積}

金型の辺縁部，歯槽頂部，口蓋部と義歯床内面の同部 分との間に生ずると思われる間隙（空間）の概略の体積
表 43 力所の概略の体積 $\left(\mathrm{mm}^{3}\right)$

\begin{tabular}{lcc}
\hline \multicolumn{1}{c}{ Materials } & $\overline{\mathrm{X}}$ & S.D. \\
\hline Acron & $323.12(\mathrm{a})^{*}$ & 19.91 \\
$\begin{array}{l}\text { Acupac 20 } \\
\text { (Heat) }\end{array}$ & $223.34(\mathrm{~b})$ & 16.20 \\
$\begin{array}{l}\text { Acupac 20 } \\
\text { (Microwave) }\end{array}$ & $179.24(\mathrm{c})$ & 10.47 \\
Triad & $177.29(\mathrm{c})$ & 15.54 \\
Acron MC & $132.81(\mathrm{~d})$ & 11.76 \\
PERform & $111.91(\mathrm{~d})$ & 11.08 \\
\hline * Multiple comparisons using & Tukey's \\
procedure. At p $\leq 0.05$, groups means \\
designated by the same letter are not sta- \\
tistically different.
\end{tabular}

を 2 の測定値より求めた. この值からも Acron MC, PERform は最も小さな值を示し, Acron は最も大きな 值を示した（表 4, 図 4).

統計処理は, まず分散の均等性 (homogeneity of variance）を調べるために Bartlett's Test を行い,この值 がカイ 2 乗検定値の 0.10 以下であったとき, 分散 分析 (analysis of variance : ANOVA) を行った. さらにこ れらの值がカイ 2 乗検定值よりも大きい時, ANOVA に 代わって WeIch Test を行った. その結果, 各平均值間 に有意差があった時, Tukey's Test により複合比較 (multiple comparison) を行った.

\section{IV. 考察}

現在，義歯床用材料としてメタアクリレートレジンが 最も一般に臨床に使用されており，そのほとんどが加熱 


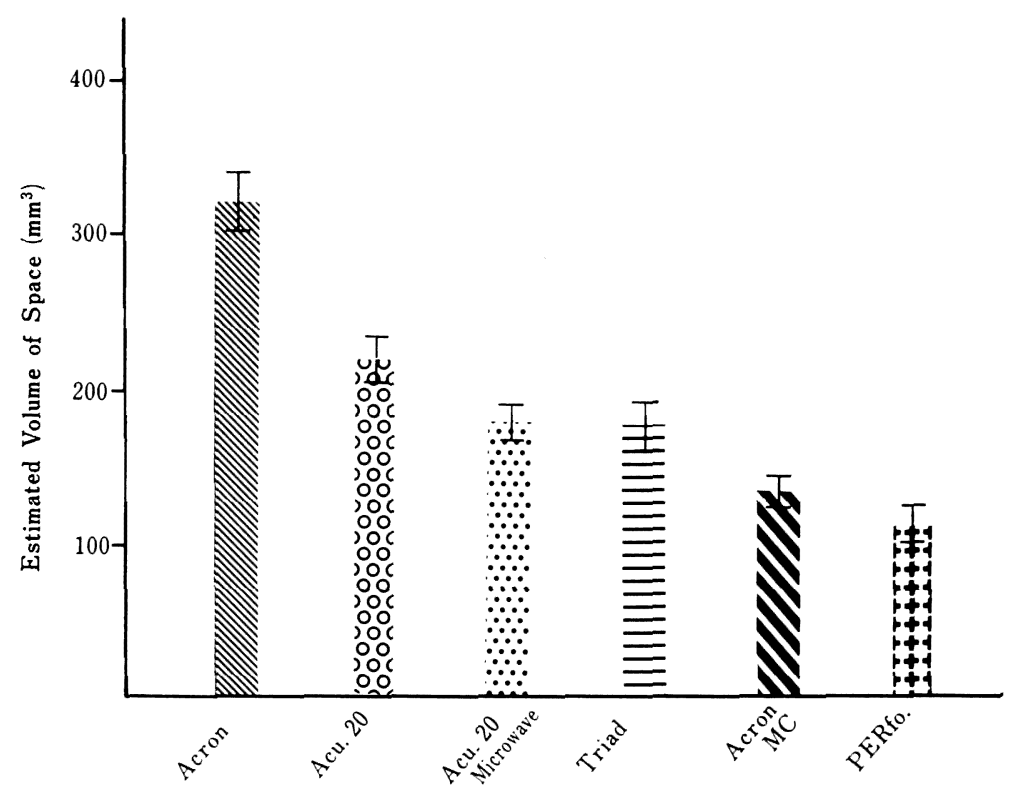

図 4 義歯床と金型との間にできた空間の概略の体積(この体皘には䫟堤の 唇煩側面，舌側面にできた空間は含まれない)

重合レジンである.このタイプのレジンは硬化反応が加 熱による重合反応であることから，重合収縮と熱収縮と を併せ持ち, 義歯床の変形, 人工歯の変位などの原因と なり, 臨床上問題点が多かった. また, 重合時間も比較 的長く，操作性においてもその改善が望まれていた. そ の後, これらの欠点を改善すべく, いわゆる常温重合レ ジンとして注入型レジン重合法が紹介され，寸法精度の 向上 ${ }^{18,26,27,43 ~ 50)}$, 重合時間の短縮, 操作性の簡便さなど から，臨床に広く用いられるようになった. しかし，こ のタイプのレジンは機械的性質が加熱重合レジンに比べ $20 \sim 30 \%$ 劣ること ${ }^{51)}$, 変色, 人工歯の脱落, 咬合高径の 低下をきたすこと施などが報告され，従来の加熱重合レ ジンに代わる義歯床用レジンにはなり得なかった。近年, 煩雑な技工操作を必要とせず，重合時間も大幅に短縮で きる義歯床用光重合レジンが開発され，その物性および 適合性について報告されている.機械的性質については， 加熱重合レジンとの比較で, 重合体の曲げ強さ, 引張り 強さに変化はなく33)，あるいは加熱重合レジン以上に機 械的強度がある ${ }^{53,54)}$ との報告もある. 適合性については, 光重合レジンシートの圧接方法, 光照射時間の影響につ いての報告はあるが ${ }^{34)}$ ，他の義歯床用レジンとの比較に 関する研究は少ない. 今回のわれわれの実験結果では, 3 通りの評価方法のいずれにおいても中間の適合性を示 し, 臨床的にはやや問題を残している. さらに, 義歯床
用光重合レジンは吸水性が非常に大きく，着色が著し い54) ともいわれ，今後の改良が望まれる. 最近，レジン 重合時の加熱にマイクロ波を用いるマイクロ波重合レジ ンが開発され，臨床に応用されるようになった. 重合時 間の大幅な短縮と均一な重合による適合精度の安定性が 得られ, 重合後の急冷, 徐冷などの泠却条件による寸法 精度も安定しており ${ }^{76)}$, 今後, 大いに期待されるレジン であろう.

このように，様々な重合方法とレジンが開発され，臨 床に応用されてはいるが，それぞれのレジンには一長一 短があり, 結局, 従来の加熱重合レジンが主流をなして いるように思われる. 本研究はこれら各種重合方法で製 作された義歯床の適合精度に着目し，重合方法の違いに よる影響を検討したものである.

\section{1. 実験材料ならびに重合方法について}

実験に使用した材料は，現在臨床に広く使用されてい ると思われる, 加熱重合レジン Acron, マイクロ波重合 レジン Acron MC, 光重合レジン Triad に加え, 短時 間加熱重合レジン Acupac 20, そして最近, 米国で発 売された注入型レジンで加圧吸引低温重合法を用いる PERform の 5 種類である.

重合方法は, 加熱重合レジン Acron については粉液 比 $100 / 40$, 予備重合として $70^{\circ} \mathrm{C}, 30$ 分, 本重合 $100^{\circ} \mathrm{C}$, 
30 分の湿熱重合とし, マイクロ波重合レジン Acron MC については粉液比 100/43, 重合は $500 \mathrm{~W}, 3$ 分とした. 光重合レジン Triad については, Triad sheet を圧接 して人工歯排列を行った後, 外側を 2 分間光照射し, 試 料を模型から取りはずし, 内側を 6 分間光照射した. 短 時間加熱重合レジン Acupac 20 は, 粉液比 100/47.6 で $100^{\circ} \mathrm{C}, 20$ 分で湿熱重合を行った.また, マイクロ波によ る重合をも試み，重合時間を予備重合として $90 \mathrm{~W}, 13$ 分, 本重合として $500 \mathrm{~W}, 1$ 分 30 秒 ${ }^{42}$ とした. 注入型レ ジンの PERform は, $45^{\circ} \mathrm{C}$ の温湯中で 30 分湿熱重合す る方式で, 重合中, 約 5.5 気圧の加圧と同時に 1.0 気圧 の吸引を行うものである.

水中浸漬した場合の加熱重合レジンのレジン硬化体の 硬化収縮は, 重合直後の硬化収縮と比較して軽減される ことから $2,4,46,55 \sim 57)$, 本実験に使用した試料む, 蒸留水中 に21 日間浸漬することとし, 測定はその後行った.

\section{2. 実験方法について}

レジン床義歯の寸法精度に関する評価方法には，大別 して臨床で実際に使用する形態の義歯を用いる方法と単 純化した形態の試料を用いる方法とがある. 実際の義歯 を用いる方法には，インディケーター・ペースト ${ }^{58) あ る ~}$ いは石亮 ${ }^{59)}$ を用いて，適合性を視診で判断する方法，シ リコーンを用いて義歯の適合性を視覚化し，画像解析装 置を用いて評価する方法 ${ }^{60)}$ がある。これらは值接, 患者 の口腔内で義歯床の適合性を評価するものである，間接 的な方法としては，石高模型あるいは金型を用いる方法 がある. 義歯床粘膜面の形態をコンパレーターを使用し て計測し, 石算模型粘膜面と比較して判定する方法61), 義歯休と石高模型との浮き上がり量を石亮模型の口蓋 部を切断して計測する方法 ${ }^{34,37,47,62,64)}$, 金型を用いて 義歯床後縁と金型後縁との浮き上がり量を測定する方 法 ${ }^{28,37,63)}$, 金型と義歯床内面との間にシリコーン印象材 を介在させ硬化後のシリコーンの重さを計量する65 69), あるいはシリコーンの厚さを測定する方法70) な゙があ る. この金型と義歯床との間にシリコーン印象材を介在 させその重さを計量する方法では，一定荷重条件下でシ リコーン印象材を硬化させることになり，荷重条件を $300 \mathrm{~g}^{63)}, 3 \mathrm{~kg}^{69)}$ とする報告があるが, 本実験ではより 実際的と思われる $3 \mathrm{~kg}$ を荷重条件とした。 また, 三次 元座標測定機を使用した報告や71,72)，ダイヤルダージを 使用して人工歯の水平的あるいは垂直的な変位量を計測 する方法 ${ }^{46,55,64,70,72)}$, 咬合器上で咬合高径の変化を計測 する方法 ${ }^{26,55,73)}$ なども報告されている.
一方, 単純化した形態の試料を用いた方法では, 標点 付きレジン平板を用い, 標点間距離の変化を計測する方 法2,44)，あるいは, 上額臼歯部の前頭断面を想定した橋脚 形金型を用い，この金型とレジン硬化体との適合を計測 寸る方法44,56,63,74,75)などがある.

このように実際臨床で用いられている形態の義歯床を 使用して寸法精度を評価する方法は, 実際的な測定值 が得やすいという反面, 測定值の再現性にそしく, 不測 の因子が含まれやすいという久点もある. しかし、レジ ン平板のように単純化した試料では, 無歯䪽顎堤の複雑 な形態の影響をみることはできず，その上，人工歯排列 の有無が義歯, 床の適合性に大きく関与しているとの報 告もある ${ }^{65)}$. 本実験では, 上堮筫歯顎堤を想定した標点つ き金型を用い，すべての試料につき人工歯排列を行い, 臨床で用いる義歯床の形態に近似させた。 また, 評価方 法は，義歯床内面と金型とに介在したシリコーンの重さ を計量することと, 義歯床と金型の後縁の閒隙量を測定 すること, さらに, 新しい試みとして, 金型の左右辺縁 部, 歯槽頂部, 口蓋部の底面積を求め, この值と後縁の 間隙量とから，これらの部分と義歯床内面に生ずると思 われる空間の概略の体積を求めた。 この值には，䫟堤の 唇・煩側面ならびに舌側面の隙間の体積は含まれていな い.

\section{3. 実験結果について}

金型と義菌床内面とに介在したシリコーン印象 材の 硬化後の重さの統計的な比較では, マイク口波重合の Acron MC, 流し込みレジンで加圧吸引低温重合レジン の PERform, 湿熱重合による短時間加熱重 合レジン Acupac 20 のそれぞれが適合性の良いグループに属し, PERform, 湿熱重合の Acupac 20，マイクロ波重合の Acupac 20, 光重合の Triad のそれぞれが中間の適合性 を示した. このうち PERform と湿熱重合の Acupac 20 は適合性の良いグループにも属し, 重複していない Acron MC がこの中でも最も適合性が良いといえる.

短時間加熱重合レジン Acupac 20 の湿熱重合と, ? イクロ波重合との重合方法の違いによる適合性の比較で は, 湿熱重合で行った時, 適合性の良いグループと中間 のグループに属し, マイクロ波重合を行った時には，中 間のグループと適合性の悪いグループとに属した. この 結果からみると, 本来, 湿熱重合用に市販されている Acupac 20 はマイクロ波の出力と重合時間を変えて予備 重合, 本重合を行っても, やや適合が悪いことになる. 光重合レジンの Triad は, 中間のグループと適合性の 
$208-1508$

補緅誌

悪いグループとに属し， 5 種類のレジンとの比較では, Acron より適合が良く, Acron MC, PERform, Acupac 20 よりは適合が悪かった. また, マイクロ波重合の Acupac 20 とは同じ結果であった.

義歯床と金型の後縁の間隙量の测定結果では，5種類 のレジンともに歯槽頂部に比べ，口蓋中央部，辺縁部の 浮き上がりが大きく，特に，口蓋中央部において著明で あった. PERform は他のレジンに比較すると部位的な差

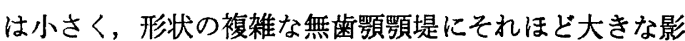
響を受けていないことが示唆された.つぎに，口蓋中央 部での間隙量をみると, PERform が最も良好な適合状態 を示し, ついで Acron MCの適合がよく, Triad とマイ クロ波重合の Acupac 20 は同じ適合状態を示した. 最 も大きな間隙量を示したのは Acron で, PERform の約 3 倍の值を示した.

金型の辺縁部，歯槽頂部，口蓋部の各底面積と義歯床 と金型の後縁との間隙量とから求めた概略の体積の比較 では, PERform と Acron MC が最も体積が小さく，良 好な適合性を示し，ついで Triad とマイクロ波重合の Acupac 20 であった. 湿熱重合の Acupac 20 の適合は マイクロ波重合の Acupac 20, Triad と比較して悪く, シリコーンの重さを比較した結果とは異なっているが, これらは歯槽堤の唇・煩側面，舌側面にできる間隙の体 積が含まれていないためと考えられる．また，口蓋中央 部における義歯床と金型との間隙量で得られた結果と同 様に, Acron は最も体積の小さい PERform の約 3 倍も の体積值を示し，義歯床と金型とに大きな間隙が生じて いることを示唆している.

各レジンの辺縁部，歯槽頂部，口蓋部のそれぞれの体 積の総和と口蓋部の体積値から口蓋部の体積の占める割 合を求め, 義歯床と金型の後縁の間隙量との関係を調へ たところ, 各レジン共に, 総体積值の 77 ～88\% を口蓋部 が占め,この部位における義歯床と金型の後縁との間隙 量とに高い相関がみられた。

このように, 加熱重合レジンの適合精度が劣る原因と しては，加熱による硬化反応がもたらす重合収縮と熱収 縮によるばかりではなく，重合収縮が発現する部位，す なわちレジン内部における重合開始部位および重合の進 行方向にも大きく左右される ${ }^{69)}$ ものと思われる. 流し込 みレジンで加圧吸引低温重合レジンの適合精度が良好な 理由は, このレジンがいわゆる常温重合レジンのタイプ で, 加熱重合レジンと比較して倀れた寸法精度を示 すためと思われる ${ }^{26,27,46,47)}$. その上, 本実験に使用した レジンは, 5.5 気圧の加圧と同時に 1 気圧の吸引を $45^{\circ} \mathrm{C}$
33 巻 6 号 (1989)

の温湯中で 30 分間の重合時間中行っているので,この 方法が適合精度を向上させているように思われるま た, マイクロ波重合レジンが良好な適合精度を示したの は, マイクロ波がレジンに吸収され，浸透力と即熱によ って，レジンの表面と内部が同時に加熱される性梊によ り，均一な重合が行われているため40) と考えられる.さ らに，その結果フラスコ内のレンジと石膏との温度差が 小さくなり，反応熱の石育への逃げやレジンの重合開始 部位による差が小さくなる゙7)ためと考えられる.

一方, 義歯床用光重合レジンによる義歯床の製作は従 来の加熱重合レジンによる方法とは大きく異なり, 操作 性の大幅な簡素化だけではなく，可視光線照射によりき わめて短時間に重合反応が開始され，常温で重合が進行 する．また，化学組成も無機質フィラーを少なくしてあ り，可撓性をもたせるために長鎖状モノマーなどが配合 してあるなど77)，工夫がされている．しかし，適合性に 関しては本実験結果では，加熱重合レジンよりは良いも のの他の重合方法よりは劣っている. その原因の 1 つと して，手指による模型面への圧接のみで何ら持続的な加 圧を行っていないためと考えられ，そのために気泡の混 入が避けられず，また，一度圧接した部分が浮き上がる 危険もある. そこで Tan $5^{78)}$ は，適合性の良い光重合 レジンの基礎床を作製するために，十分乾燥した模型上 で手指による圧接を行った後，ラバーダムを介して，真 空加圧する方法を提唱している.

\section{V. 結 論}

重合様式の異なる 5 種類の市販義歯床用レジンを使用 し，臨床にできるだけ近い形態の義歯床を製作し，その 適合精度について検討したところ以下の結論を得た.

1. 最も適合が良かった義歯床用レジンは，流し込み レジンで加圧吸引低温重合レジン PERform とマイクロ 波重合レジンAcron MC であった.

2. 光重合レジン Triad, 短時間加熱重 合レジン Acupac 20 (湿熱重合法とマイクロ波重合法) は，中間 の適合精度を示した。

3. 最も適合が悪かった義歯床用レジンは，加熱重合 レジン Acronであった.

\section{文献}

1) Sweeney, W.T. : Denture base material, J Am Dent Assoc, $26: 1863 \sim 1873,1939$. 
2) Harman, I.M. : Effects of time and temperature on polymerization of a methacrylate resin denture base, $\mathrm{J}$ Am Dent Assoc, 38 : 188 203, 1949.

3）增原英一，楆見二郎：歯科用合成樹脂の性倎改善に関する 総合的研究 (第 5 報) 歯科用アクリリックレジンの性梊に 対するポリマーの粒度並びに平均重合度の影響について, 歯材研報, $1: 25 \sim 33,1953$.

4) Woelfel, J.B., Paffenbarger, G.C. and Sweeney, W.T. : Dimensional changes in complete dentures on drying, wetting and heating in water, J Am Dent Assoc, 65 : 495 505, 1962.

5) Woelfel, J.B., Paffenbarger, G.C. and Sweeney, W.T. : Some physical properties of Organic Denture Base Materials, J Am Dent Assoc, 67 : 489 509, 1963.

6）木村賢亮：メタクリレート系コポリマーの粉末を使用した 床用樹脂の試作研究，歯理工誌， $12: 15 \sim 38,1971$.

7）平澤 忠, 月野光男, 山根正次 : 歯科用メタクリルレジン に関する研究 (第 2 報) 床用メタクリルレジンの物理的性 質について, 歯理工誌, $12: 101 \sim 111,1971$.

8）武田 耕：過酸化ベンゾイルーアミン触媒を使用した義苗 床用樹脂の試作に関する研 究, 畨材器誌, $24: 51 \sim 71$, 1971.

9）井上忠志 : 床用レジンの餅状化期間延長に関する研究，日 大齿学, $49: 347 \sim 363,1972$.

10）江藤世助：歯科休用レジンの餅状化期間延長に関する 研 究, 歯材器誌, $31: 46 \sim 60,1974$.

11）武田幸一：床用レジンの餅状期間の延長とそれに伴う物性 の低下防止に関する研究, 歯材器誌, $33: 61 \sim 77,1976$.

12）堀内 哲：床用レジンの餅状期間の延長とそれに伴う物性 の低下防止関する研究, 歯材器誌, $33: 256 \sim 269,1976$.

13) Ruyter, I.E. and Svendsen, S.A. : Flexural properties of denture base polymers, J Prosthet Dent, $43: 95 \sim 104$, 1980.

14) Haegreaves, A.S. : The effect of cyclic stress on dental polymethyl methacrylate, I. Thermal and environmental fluctuation, J Oral Rehabil, $10: 75 \sim 85,1983$.

15）平林 茂, 中西 敏, 立野治雄ほか：歯科用メタクリルレ ジンに関する研究 (第 10 報) 加熱重合レジン, ヒートシ ヨックレジン, 流し込みレジンおよび常温重合レジンの物 理的性犋について, 柬材器誌, $3: 350 \sim 358,1984$.

16) Shepard, W.L. : Denture bases processed from a fluid resin, J Prosthet Dent, $19: 561 \sim 572,1968$.

17）熱田 充, 安田 登, 增原英一：流し込み法による正確な レジン床のつくり方, DE, $17: 4 \sim 13,1971$.

18）松本直之, 佐久間清文 : 流し込みレジンの加工精度, 補緅 臨床, $4: 117 \sim 123,1971$.

19）安田 登, 佐藤 浩, 中林宣男ほか：流し込みレジンのス プルー形態と重合収縮・人工齿の移動, 歯界展望, 44 :
498 504, 1974.

20）增原英一, 春日 均, 堀内 章ほか：コアーシステムによ る金属床, レジン床義歯の作り方, DE, $38: 1 \sim 9,1976$.

21）Kulzer 社 : 油压注入式射出成形精密デンチャー作製シス テム〈イントプレス〉, Kulzer 社マニュアル, 1 7, 1977.

22）小杉緑朗：レイニング工法とその臨床応用（その1）, 日 本歯科評論, $462,141 \sim 152,1981$.

23）森 博史, 可児光弘, 大崎千秋ほか : 加圧填入方式による 加熱重合レジンの技工的評価，歯科技工, $9: 209 \sim 219$, 1981.

24）佐藤 浩, 門磨義則, 中林宜男ほか: 歯科用アクリリック レジンに関する砳究, 歯理工誌, $18: 46 \sim 56,1977$.

25）立野治雄 : 義歯床用加熱重合レジンの寸法精度による基碟 的研究，鶴見歯学, $11: 89 \sim 107,1985$.

26）松本直之, 佐久間清文 : 流し込みレジンの加工精度, 補緅 臨床, $4: 117 \sim 123,1971$.

27）奥野善彦, 丸岡宽昭，野首孝柌ほか：注入型レジンに関す る基整的研究, 阪大歯誌, $17: 46 \sim 55,1972$.

28）岡井良道, 池田隆史, 中村 聡ほか：高加圧持続式加熱重 合法によるレジン休義歯の適合精度は，畨科技工， 13 ： 21 25, 1985.

29）津留宏道, 吉田耕一郎, 池田隆彦: ポリエーテルサルホン 樹脂を用いた総義歯の製作法, $\mathrm{DE}, 82: 2 \sim 7,1987$.

30）奥野善彦，野首孝祠，中平良基 : ポリエーテルサルホン樹 脂を用いたパーシャルデンチャーの製作法, DE, $82: 8$ 15, 1987.

31）津留宏道, 吉田耕一郎：スミプロイデンチャーシステムに よるポリエーテルサルホン義歯製作法, DE, $81: 28 \sim 31$, 1987.

32）村岡 博, 石川功和 : 光重合レジンによる有床義歯製作シ ステムートライアドシステムの特徴とその物性, 歯科技工, $13: 528 \sim 536,1985$.

33）後藤ひろみ, 宇美隆生, 青山芳博ほか : 可視光線重合型床 用レジンの基礎的研究一第 1 報 機械的性犋について一, 補緅誌, $30: 387 \sim 391,1986$.

34）青山芳博, 宇美隆生, 後藤ひろみほか：可視光線重合型床 用レジンの基硔的研究一第 2 報 物性および適合性につい て一, 補緅誌, $30: 719 \sim 723,1986$.

35）宇美隆生, 青山芳博, 後藤ひろみほか : 可視光線重合型床 用レジンの基硕的研究一第 3 報 適合性の検討一，日大歯 学, $60: 410 \sim 414,1986$.

36) 木村 博, 寺岡文雄, 斎藤隆裕ほか：マイクロ波の歯科人 の応用 (その 1)ーレジンのドウ化とキュアリングー, 歯 材器, $2: 253 \sim 257,1983$.

37）木村 博, 寺岡文雄, 大西寞保ほか：マイクロ波の歯科一 の応用 (その 2)ーレジンの適合性一, 歯材器, $2: 451 \sim$ 457, 1983.

38）木村 博, 寺岡文雄, 大西寞保ほか：マイクロ波の歯科へ 
の応用 (その 3 )ーレジンの表面粗さと石こうとの分離 性一, 歯材器, $2: 772 \sim 776,1983$.

39）安藤申直，今野一敏，長田伸一ほか：マイクロ波重合法に よるアクリリックレジン床の内面適合，歯科技工， 15 ： $354 \sim 362,1987$.

40）橋本弘一：マイクロウエーブ重合の概要，歯科技工， 15 : $341 \sim 346,1987$.

41）鈴木一臣：マイクロ波重合型義歯床用レジンの理工学的性 質，歯科技工， $15: 347 \sim 353 ， 1987$.

42) Takamata, T., Setcos, J.C. and Phillips, R.W. et al : Adaptation of acrylic resin dentures as influenced by the activation mode of polymerization, J Am Dent Assoc, $119: 271 \sim 2761989$.

43) Osborne, J.: Internal strains in acrylic denture base materials, Br Dent J, $16: 204 \sim 212,1947$.

44）原田義雄：義歯床用常温重合樹脂に関する研究, 口病誌, $32: 291 \sim 312,1965$.

45）永田勝久：歯科用流し込みレジンに関する研究 (II）架橋 剤濃度と重合時の加圧が寸法精度に及ぼす影響について， 歯理工誌, $17: 239 \sim 246,1976$.

46) Mowery, W.E., Burns, C.L. and Dickson, G. et al : Dimensional stability of denture base resins, J Am Dent Assoc, $57: 345 \sim 353,1958$.

47) Woelfel, J.B., Paffenbarger, G.C. and Sweeney, W.T. : Dimensional changes occuring in dentures during processing, J Am Dent Assoc, 61 : 414 430, 1960.

48) Goodkind, R.J. and Schulte, R.C. : Dimensional accuracy of pour acrylic resin and conventional processing of cold-curing acrylic resin bases, J Prosthet Dent, 24 : $662 \sim 668,1970$.

49) Garfunkel, E. : Evaluation of dimensional changes in complete dentures processed by injection-pressing and the pack-and-press technique, J Prosthet Dent, 50 : $757 \sim 761,1983$.

50) Anderson, G.C., Shulte, J.K. and Arnold, T.G. : Dimensional stability of injection and conventional processing of denture base acrylic resin, J Prosthet Dent, 60 : $394 \sim 398,1988$.

51）平澤 忠, 原嶋郁郎：義歯床用常温重合レジン，歯科技工 別冊, 義歯床用レジンと歯科技工 : 38 47, 1982.

52）平澤 忠, 加藤武彦, 丸山松司ほか：補綴臨床における義 歯床用レジンの有用性をめぐって，歯科技工別冊，義歯床 用レジンと歯科技工 : 3 18, 1982 .

53) Ogle, R.E., Sorensen, S.E. and Lewis, E.A. : A new visible light-cured resin system applied to removable prosthodontics, J Prosthet Dent, 56 : 497 506, 1986.

54) Khan, Z., von Fraunhofer, J.A. and Razavi, R.: The staining characteristics, transeverse strength and mi- crohardness of a visible light-cured denture base material, J Prosthet Dent, $57: 384 \sim 386,1987$.

55）奥野善彦, 佐野敂一, 野首孝的的 : 注入型レジン重合法 における人工歯の移動と咬合高径の変化について一特殊石

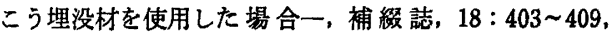
1975 .

56）丸岡寬昭 : 石卒模型の膨張がレジン床義歯の適合度に及ぼ 寸影響に関する研究，阪大歯誌，16:29 44，1971.

57) Takahashi, M., Shen, M.C. and Taylor, R.B. et al : Master curves for some amorphous polymers, J Appl Polymer Sci, 8 : 1549 1561, 1964.

58) Woelfel, J.B. and Paffenbarger, G.C. : Pressure-indicator-paste patterns in duplicate dentures made by different processing techniques for the same patients, $\mathrm{J}$ Am Dent Assoc, $70: 339 \sim 343,1965$.

59) Young, J.M. : A study of the accuracy of the apposition of palatal tissues to complete dentures, J Prosthet Dent, $23: 136 \sim 147,1970$.

60）細井紀雄 : 義歯床の適合試験法に関する研究, 鶴見歯学, $2: 111 \sim 134,1976$.

61) Anthony, D.H. and Peyton, F.A.: Dimensional accuracy of various denture-base materials, J Prosthet Dent, 12 : $67 \sim 81,1962$.

62）川良美佐雄 : 床用レジンの填塞・温成法に関する補緅学的 検討 上顎総義歯について, 日大口腔科学, $7: 375 \sim 388$, 1981.

63）加藤仁朗, 西井正道, 上谷逸朗ほか : 各種ヒートショック 型床用樹脂の比較検討, 歯材器誌, $17: 51 \sim 60,1968$.

64）平沼謙二：義歯床用レジンの理工学的試験 とくに, 人工 歯の変位よりみた寸法精度の検討，日歯医 師 会 誌， 36 : 849 856, 1983.

65) Barco, M.T. Jr. : Maxillary complete denture stability : Part $1:$ In vitro dimensional accuracy, Part $2:$ In vivo stability, Master's Thesis, Indiana University School of Dentistry, 1979.

66) Mainieri, E.T. : Tooth movement and dimensional change of denture base materials using two different type of investing, Master's Thesis, Indiana University School of Dentistry, 1979.

67) Sayoc, A.M. : Effect of sterilization technique on plastic maxillofacial implant materials, Master's Thesis, Indiana University School of Dentistry, 1983.

68) Shlosberg, S.R. : Microwave curing of Poly (methyl methacrylate) denture base resin, Master's Thesis, Indiana University School of Dentistry, 1987.

69）永田勝久，佐藤雅彦，中林宣男ほか：重合収縮の発現部位 と義歯床の適合精度について, 歯理工誌, $19: 153 \sim 158$, 1978. 
70）木村 博, 游 本淵, 寺岡文婎 : 義齒床用レジンの開発に 関する研究 (第 1 報) 人工歯の移動と適合性について, 歯 材器誌, $6: 888 \sim 893,1987$.

71）稲永昭彦, 宮口裕美, 岡喜七郎ほか：義歯床用レジンに関 する研究 第 2 報 INTOPRESS の床粘膜面部における 適合性について, 福岡歯大誌, $9: 215 \sim 226,1982$.

72）潤米宏仁, 久保田幸生, 山田博明ほか：調製過程における 総義踩の三次元的寸法変化 第 1 報 人工歯の変位量拉よ び義歯床の形状変化について, 補 緅 誌, $30: 155 \sim 168$, 1986.

73) Dukes, B.S., Fields, H. Jr. and Olson, J.W. et al : A laboratory study of changes in vertical dimension using a compression molding and a pour resin technique, $\mathrm{J}$ Prosthet Dent, 53 : 667 669, 1985.
74）中井宏之, 東口茂治, 辻合和雄ほか：義齒作製時の諸条件 がその再現性に及ぼす影警について（その1)，歯材器誌， $12: 43 \sim 52,1965$.

75）山賀谷一郎 : 床用レジンの品質改良に関する研究 親水 性・琉水性レジンの配合比の変化および架橋材添加の効果 について, 歯材器誌, $38: 341 \sim 358,1981$.

76）内田欣臣, 岡本史江, 尾形和彦ほか：マイクロ波重合型義 歯床用レジンの寸法精度, 補緅誌, $33: 114 \sim 118,1989$.

77）增原英一，松村英雄：技工に役立つ高分子歯科材料の知 識, QDT, $9: 100 \sim 106,1984$.

78) Tan, H.K., Brudvik, J.S. and Nicholls, J.I. et al : Adaptation of a visible light-cured denture base material, $61: 326 \sim 331,1989$. 